スプレー造粒粉を用いた Nd-Fe-B 焼結磁石の磁気特性 (IV)

\author{
岸本 芳久社，山下. 治虰

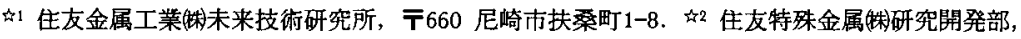 \\ T618 大阪府三島郡島本町江川2-15-17.
}

\title{
Magnetic Properties of Nd-Fe-B Magnets Sintered Using Granulated Powders by Spray Drying Method (IV)
}

\author{
Yoshihisa Kishimoto ${ }^{\text {\1 }}$ and Osamu Yamashita \\ t1 Advanced Technology Research Laboratories, Sumitomo Metal Industries, Ltd., 1-8 Fuso-cho, \\ Amagasaki 660. Research \& Development Department, Sumitomo Special Metals Co., Ltd., \\ 2-15-17 Egawa Shimamoto-cho Mishima-gun, Osaka 618.
}

Received June 3, 1997

\section{SYNOPSIS}

$\mathrm{Nd}-\mathrm{Fe}-\mathrm{B}$ alloy powder was granulated by a spray drying method using organic binder consisted of polyvinylalcohol or cellulose ethers, in order to improve the powder flowability during feeding and compacting. The compressing behavior of Nd-Fe-B granulated powders was investigated. In the case of granulated powders, the relation between compressing stress and powder bulk density was expressed by two straight lines containing one bending point, and the compressing stress on this point was defined as the average destruction strength(ADS). The ADS was closely related with the tensile strength of organic binder. By means of controlling the tensile strength of binder by changing its composition or polymer/plasticizer ratio, the ADS could be designed easily. In the case that the ADS was less than about $0.1 \mathrm{~N} / \mathrm{mm}^{2}$, the powder flowability of granulated powder was improved with increasing the ADS, whereas in the case of more than about $0.1 \mathrm{~N} / \mathrm{mm}^{2}$, it showed almost constant value. The magnetic characteristics (remanences and maximum energy product) of sintered magnets using granulated powders were improved proportionally with decreasing the ADS, which was independent of any kinds of polymers and binder composition. These facts mean that the degree of the magnetic orientation of primary particles in granulated powders under a magnetic field can be determined simply by the ADS.

\section{KEY WORDS}

spray drying, Nd-Fe-B magnet, organic binder, plasticizer

\section{1 緒 言}

$\mathrm{Nd}_{2} \mathrm{Fe}_{14} \mathrm{~B}$ 希土類磁石 ${ }^{1)}$ の高性能化とともに，磁石寸 法の小型化，高性能化が求められているが，焼結用の 合金粉末についての造粒技術はこれまであまり研究さ れていない状況である。そこで著者らは焼結磁石の寸 法精度の向上を目的に, 希土類系合金粉末のスプレー 造粒技術2)に着目し，ポリビニルアルコール，七ル ロースエーテル類等のポリマーと可塑剤からなるバイ ンダーを用い，優れた粉末の流動性を有しかつ磁石特 性の低下が少ない焼結体が得られることを報告した3.5). これまでの知見から， $\mathrm{Nd}_{2} \mathrm{Fe}_{14} \mathrm{~B}$ 希土類磁石の造粒技術
においては，高強度バインダーを用いることにより， 得られる粉末の流動性は向上するが, 焼結体の磁場配 向性は逆に低下することがわかっているあ。.これは造 粒粉末の機械的強度が両特性に大きく関与しているた めと考えられこれらの関係をさらに明確化するため に, 造粒粉末の圧縮挙動と焼結体の磁石特性（磁場配 向性）との関係を詳細に検討したのでその結果を報告 する。

\section{2 実験方法}

実験に使用したNd-Fe-B 合金粉末は，市販のネオジ 
Table 1 Chemical analysis and average particle size of Nd-Fe-B alloy powder.

\begin{tabular}{|c|c|c|c|c|c|}
\hline \multicolumn{5}{|c|}{ Composition (wt\%) } & \multirow{2}{*}{$\begin{array}{l}\text { Average particle } \\
\text { size }(\mu \mathrm{m})\end{array}$} \\
\hline $\mathrm{Nd}$ & B & $\mathrm{Fe}$ & $\mathrm{O}$ & $\mathrm{C}$ & \\
\hline 31.0 & 1.1 & Bal & 0.63 & 0.05 & 4.1 \\
\hline
\end{tabular}

ウム、鉄および硼素を高周波溶解し，そのインゴット を粉砕して作製した. Table 1 に合金組成の化学分析值 と平均粒径を示す.スプレー造粒の工程は, ポリビニ ルアルコール (PVA), カルボキシメチルセルロース (CMC), メチル七ルロース (MC) 等のポリマーとグリ セリン等の可塑浏からなるバインダーを用いて既報了-6) の条件に従い行った。

得られた造粒粉末を直角磁場 $(0.88(\mathrm{MA} / \mathrm{m}))$ 中で压 縮成形した後, 水素雾囲気中で脱脂し，真空中で脱水 素した後, $1393 \mathrm{~K}$ の温度で 4 時間焼結を行った，さら に焼結後 $773 \mathrm{~K}$ の熱処理を 2 時間行った後, (BH) 卜 レーサーにより磁石特性を測定した。

粉末の圧縮挙動の解析は, 円筒状セルに粉末を充填 し蓋をして，圧縮試験機（ホソカワミクロン (株) 製 “アグロボット”）により压縮応力一嵩密度の関係を調 ベることにより行った7.8). Table 2 に測定条件を示す.

Table 2 Experimental conditions of compressive analysis for granulated powders.

\begin{tabular}{lc}
\hline \multicolumn{1}{c}{ Item } & Condition \\
\hline Weight of sample powder & $0.3 \mathrm{~kg}$ \\
Cell diameter & $25 \mathrm{~mm}$ \\
Cell temperature & $293 \mathrm{~K}$ \\
Compressing speed & $3.0 \times 10^{-3} \mathrm{~m} / \mathrm{sec}$ \\
Maximum compressing stress & $4.0 \mathrm{~N} / \mathrm{mm}^{2}$ \\
\hline
\end{tabular}

\section{3 結果と考察}

\section{1 造粒粉末の圧密応力一禽密度特性}

造粒顆粒化した $\mathrm{Nd}_{2} \mathrm{Fe}_{14} \mathrm{~B}$ 希土類合金粉末を用いて焼 結永久磁石を製造するにあたり，造粒粉末が球状で優 れた流動性を有しかつ磁場中プレス成形時に容易に一 次粒子に解砕され充分磁場配向されることが必要であ る.まず造粒粉末，原料粉末および内部潤滑粉")の圧 密応力一嵩密度特性の関係を Fig.1に示す.ここで内部 潤滑粉末は合金粒子間の潤滑性を向上させるため，あ らかじめアルキルボレート系潤骬郕を $0.2 \mathrm{wt} \%$ 添加混合 したものを用いた. 原料粉末および内部潤滑粉末の場 合には，ほほ一様に圧密が進行してゆく，原料粉末に 潤滑剂を添加混合することにより，粉末粒子間の摩擦

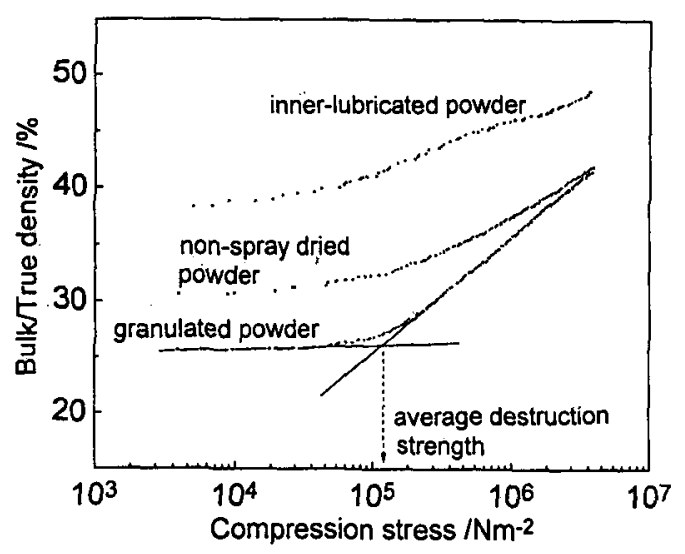

Fig.1 Typical compression stress-bulk density plots of granulated powders, non-spray dried powder and innerlubricated powder.

カが低減し，同じ応力に対しても圧密性が優れること がわかる。これに対して造粒粉末の場合には図中に示 すように, 初期圧密過程では造粒粉末の再配列と考え られる充填が起こり楥やかに容密度が増大し, さらに 圧綰を加えていくと特定の圧縮応力を境に急激な訔密 度の増加が始まり, ほほ一样に圧密が進み, 最大荷重 下では原料粉末の場合とほほ同等の嵓密度に達する。

そこで，この造粒粉末の圧縮举動々粉末の状態を関 連づけるために, 任意の圧縮応力下での造粒粉末の電 顕写真をPhoto.1に示す. 写真よりわかるように, 圧密 の初期過程では一部造粒粉末の崩壊も見られるが，ほ ばその形状が保持された状態で緩やかな圧密が進行し ている，そして，圧密の進行が進み始めるとともに崩 壊している粒子の数が徐々に増加し, 屈曲点近傍 (図 中 C)においては約半数程度の造粒粉末が崩壊してい る.さらに圧密が進行するとほとんどの造粒粉末は崩 壊していることがわかる。

すなわち，この傾きが大きく変化する点での圧縮応 力が造粒粉末の崩塤強度々関連し, 造粒粉末の成形性 のみならす磁場中成形時の磁場配向性, および造粒粉 末自体の流動性等に大きく影響を及ほすものと予想さ れる. そこで，これらの測定の結果から，この屈曲点 は, 平均的な強度を有する造粒粉末が崩壊する圧力で あり，造粒粉末の崩壊挙動のパラメーターとして， 


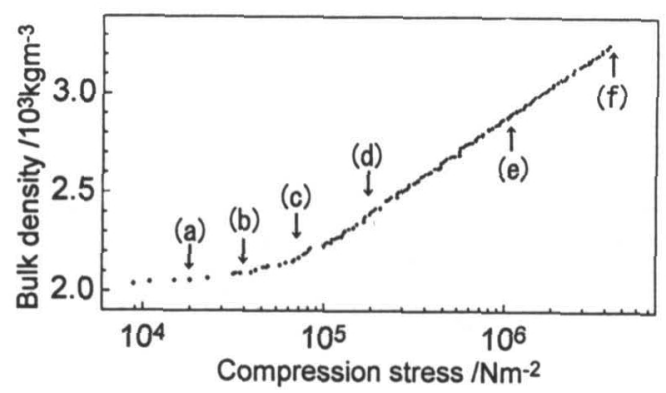

(a) $2 \times 10^{4} \mathrm{~N} / \mathrm{m}^{2}$

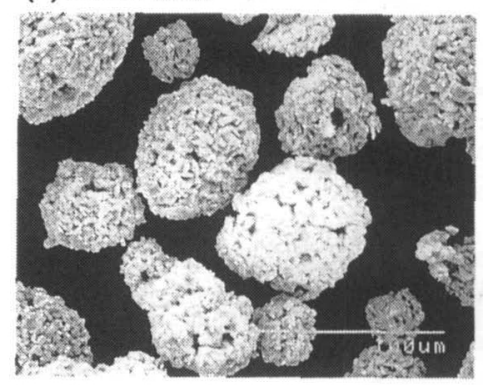

(d) $2 \times 10^{5} \mathrm{~N} / \mathrm{m}^{2}$

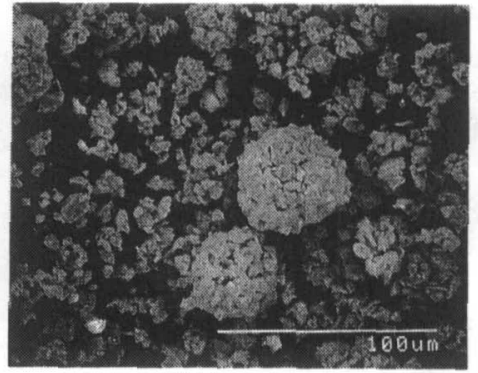

(b) $4 \times 10^{4} \mathrm{~N} / \mathrm{m}^{2}$

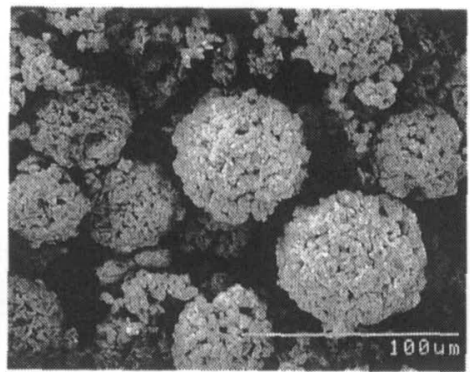

(e) $1 \times 10^{6} \mathrm{~N} / \mathrm{m}^{2}$

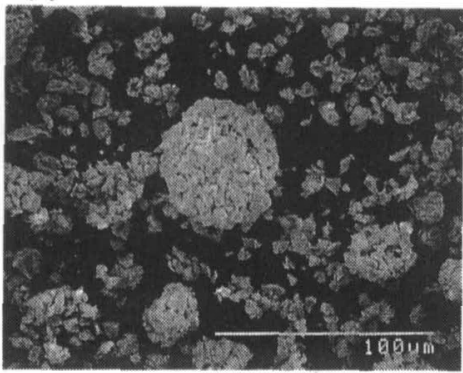

(c) $7 \times 10^{4} \mathrm{~N} / \mathrm{m}^{2}$

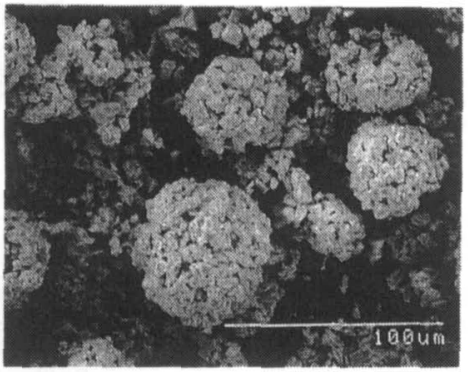

(f) $4 \times 10^{6} \mathrm{~N} / \mathrm{m}^{2}$

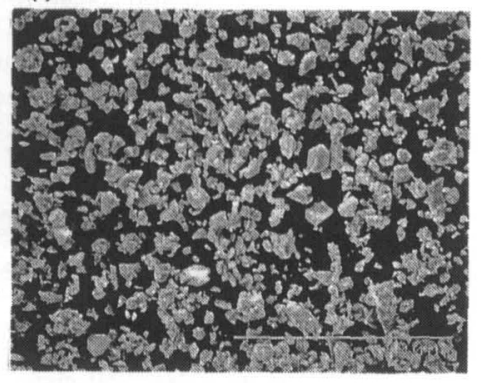

$100 \mu \mathrm{m}$

Photo.1 Scanning electron micrographs of granulated powders on compressing analysis. Each compressing stress and bulk density are shown in figure and photographs. These powders were granulated using organic binder consisted of $0.2 \mathrm{wt} \%$ PVA and $0.06 \mathrm{wt} \%$ glycerin.

Fig.1に示すように初期圧縮過程および後期圧縮過程で のそれぞれの接線の交点を与える圧縮応力を, 便宜上 その造粒粉末の平均崩壊強度と定義した.

3.2 バインダー組成と平均崩壊強度の関係

これまでの報告から，造粒粉末の流動性および得ら れる磁石特性は用いるバインダーの配合量およびバイ ンダー単体の破断強度に大きく依存することを明らか にしてきた6.そそこで，まずポリマーとしてPVA，MC を用いてバインダー配合量と圧縮特性の関係を調べた。

Fig.2に2種類のバインダー系におけるポリマー添加 量と平均崩壊強度および平均崩壊強度をあたえる粉末 密度の関係を示す。平均崩壊強度は, ポリマー添加量 とともに一様に増加する。これは, $0.5 \mathrm{wt} \%$ 以下のバイ ンダー添加量では, 体積換算では粉末の空隙の一部を
埋める程度の配合量であることから, 添加したバイン ダーはほほ完全に合金粉末粒子間の結合剤として作用 していると考えられる. 従って, バインダー配合量を 増加させることにより，合金粉末間の結合面積が増加 し, バインダー配合量の増加とともに一様に平均崩壊 強度が向上したものと考えられる。一方，その平均崩 壊強度を与える粉末密度は, バインダー量の増加とと もにわずかに低くなる傾向にあるが, ほほ一定の值と なる、これは，上述のように造粒粉末が，圧縮初期の 過程で粉末の再配列がおこった後, 圧縮応力の増加と ともに造粒粉末の崩壊が始まることから, 造粒粉末の 粒径, 形状に大きな差がなければ崩壊がおこる粉末密 度は一定と考えられる。また, バインダー配合量が極 端に少ない $0.1 \mathrm{wt} \%$ の場合に平均崩壊時の密度が高く 

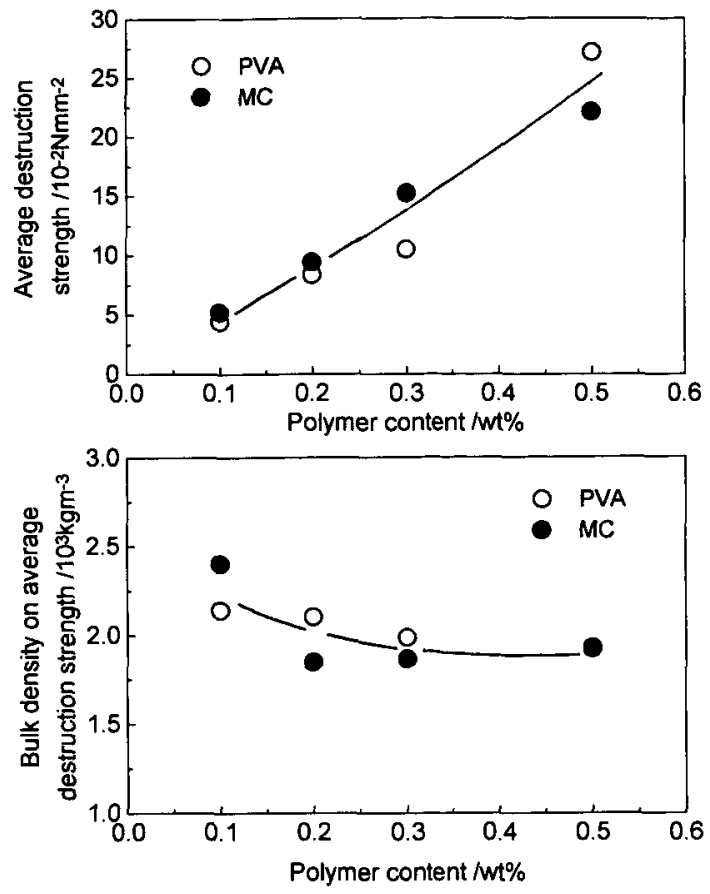

Fig. 2 Relations between additional polymer content in granulated powders and average destruction strength or bulk density on average destruction strength.

なっているのは，造粒性が十分ではなく，末造粒微粉 末が残存しているため初期状態から充填密度が上昇し ているためと考えられる。

これまでの報告わから（バインダー中の可塑剂量を 増加させることにより磁場中成形時の配向性は大きく 向上することがわかっている．そこでこれらの現象と 造粒粉の強度との関連を検討するために可塑剂配合量 と圧縮挙動との関係を調べた. ポリマーとしてPVAお よびCMCを，可塑乳としてグリセリンを用いた場合 の可塑剂/ポリマー配合比 (P/P 比) と造粒粉末の平均 崩壊強度および平均崩壊強度を与える粉末密度の関係 をFig.3に示す、既報で述べたように，ポリマー単体の 物性としてはCMCの方がPVAより破断强度は大き く,グリセリンの可塑効果はCMCに対してよりも PVAに対しての効果が大きい6)，ポリマーとしてPVA を用いた場合, 眓から明らかなようにポリマー添加量 には大きく依存せず可塑凨添加量の增大とともに平均 崩壊強度は低下する。これは, 著しい可塑効果により バインダー単体の破断強度が低下し, 粒子間結合力が 低下したためと考えられる。一方，ポリマーとして CMCを用いた場合， CMC 自体の破断強度が高いと同 時にグリセりンの可塑効果が低いことにより, PVA系
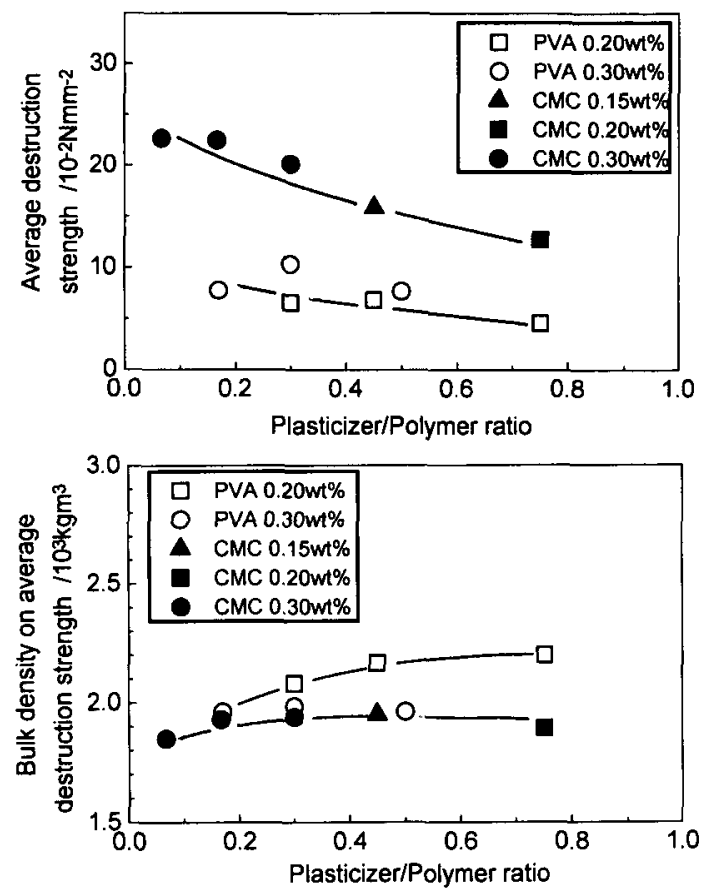

Fig.3 Relations between plasticizer/polymer weight ratio in binder and average destruction strength or bulk density on average destruction strength.

に比べ合金粒子問結合力が向上し，その結果平均崩壊 強度は大きくなり，PVAの場合と同様に，ポリマー添 加量よりも可塑剤添加比に大きく依存することがわ かった。一方, 平均崩壊強度を与える粉末密度も $\mathrm{P} / \mathrm{P}$ 比 の増大とともにわずかに大きくなる，これは可塑剤量 の増加とともにバインダーの結合力が低下し，圧縮初 期の再配列過程において徐々に粉末が崩壊を始めるた め, 圧縮応力ー嵩密度プロット上の平均崩壊強度を与 える密度が上昇したものと考えられる。また，ポリ マー間の比較においても, PVAより破断強度の高い $\mathrm{CMC}$ 系が造粒粉末の保形性に優れることから平均崩壊 強度を与える粉末密度は小さくなる。

次に, 可塑剤の種類とバインダー物性および平均崩 壊強度の関係を調べた。ポリマーとしてPVAを用い, 各種可塑郕を所定比率 (PVA/可塑剤 $=1.0 / 0.3$ 重量比) に配合して作製したバインダーフィルムの機械物性を Table 3に示す.このように用いた可塑剤の可塑効果に より,バインダーの破断強度, 延性は異なる。これら のバインダーを用いて造粒顆粒化した場合の，バイン ダー単体の破断強度と造粒粉末の平均崩壊強度の関係 を Fig.4に示す.このように, バインダーの破断強度と 平均崩壊強度はよい相関関係にあり,バインダー自体 
Table 3 Mechanical properties of binder films consisted of PVA and several plasticizers.

\begin{tabular}{llccc}
\hline Polymer & Plasticizer & $\begin{array}{c}\text { Mixing ratio } \\
\text { (weight ratio) }\end{array}$ & $\begin{array}{c}\text { Tensile strength } \\
\left(\mathrm{N} / \mathrm{mm}^{2}\right)\end{array}$ & $\begin{array}{c}\text { Elongation } \\
\text { (A.U.) }\end{array}$ \\
\hline PVA & Glycerin & $1.0 / 0.3$ & 5.64 & 2.30 \\
PVA & 1,3-propanediol & $1.0 / 0.3$ & 6.19 & 2.73 \\
PVA & 3-Methyl-1,3-butanediol & $1.0 / 0.3$ & 7.35 & 2.61 \\
PVA & Dipropylene Glycol & $1.0 / 0.3$ & 7.47 & 2.24 \\
PVA & Triethylene Glycol & $1.0 / 0.3$ & 5.78 & 3.87 \\
PVA & 1,4-Butanediol & $1.0 / 0.3$ & 6.06 & 3.19 \\
\hline
\end{tabular}

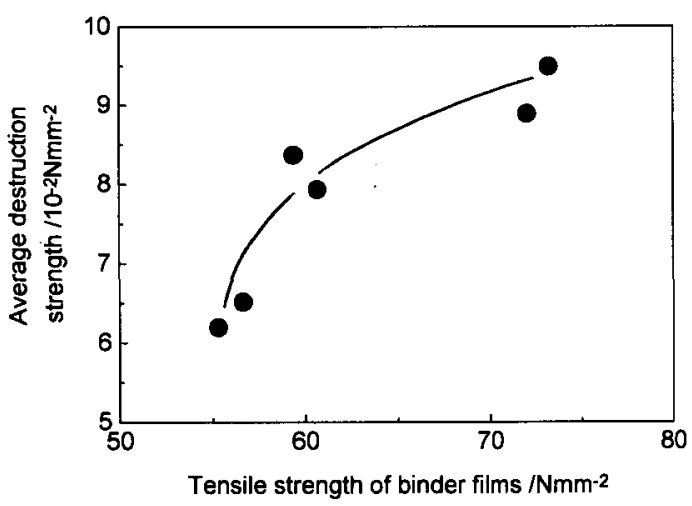

Fig.4 Relation between tensile strength of binder films consisted of PVA and each plasticizer and average destruction strength of powders granulated using each binder.

の破断強度の増加とともに平均崩壊強度は上昇する。 このことは，平均崩壊強度を支配する因子として，合 金粉末一バインダー間界面の密着性よりもバインダー 自体の破断強度が大きく奇与していることを示唆する ものである. 従って，造粒用バインダーの配合組成を 設計する場合, ポリマー自体の機械的物性と同時に用 いる可塑剤の可塑効果に着目して最適組成を設計する 必要がある.

\section{3 造粒粉末の平均崩壊強度と粉末特性の関係}

造粒粉末の平均崩壊強度は, 造粒粉末の機械的物性 として簡便に測定でき，かつ重要なパラメーターであ ることが明らかになった．そこで造粒顆粒化の目的で ある粉末の流動性の向上効果と造粒粉末の平均崩壊強 度との関係を調べた．その結果を Fig.5に示す。なお粉

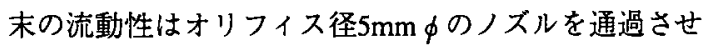
て，その通過時間を測定する規格 JIS z 2505 に基づき 測定した.このように, 平均崩壊強度が約 $0.1 \mathrm{~N} / \mathrm{mm}^{2}$ 以 下の領域では, 平均崩壊強度の増加とともに流動性は 向上するが, 約 $0.1 \mathrm{~N} / \mathrm{mm}^{2}$ 以上になると平均崩壊強度に 依存せずほほ一定の值となる。このことは，均一で良 好な流動性を有する顆粒粉末を得るためにはある一定

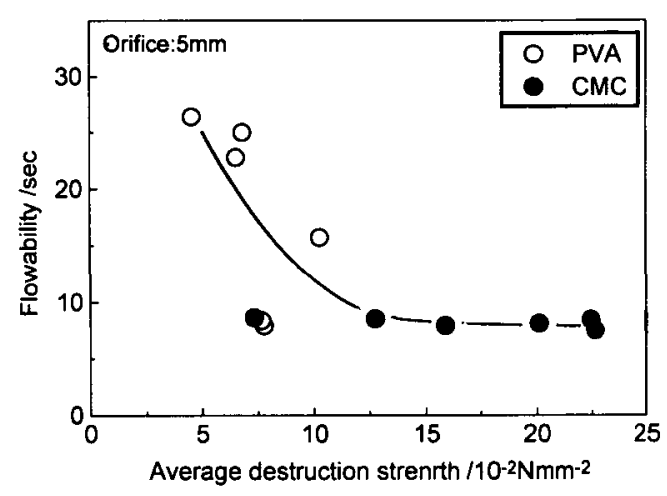

Fig.5 Relations between average destruction strength and flowabilities of granulated powders. The flowability was measured as the time for powder of $30 \mathrm{~g}$ to naturally fall through a funnel tube with an orifice of $5 \mathrm{~mm}$.

の崩壊強度は必要であるが, それ以上崩壊強度を高め て造粒粉末自体を強固なものにしても，流動性を向上 させる効果はほとんどないことを示している。すなわ ちプレス成形性を考虑すると必要以上に造粒粉末の崩 壊強度を向上させることは，逆にグリーン体の強度を 低下させ,生産性の低下を招く恐れがあり，造粒粉末 の平均崩壊強度は必要最低の值に設計するべきである. 3.4 造粒粉末の平均崩堘強度と永久磁石特性の関係 これまで述べてきたように，造粒粉末特性のバラ メーターとして平均崩壊強度を導入し, バインダー組 成および粉末の流動性等に平均崩壊強度が密接に関 わっていること明らかにした。 ところで，既報で述べ たように造粒粉末を用いて得られる焼結永久磁石の磁 気特性, 特に残留磁束密度 $(\mathrm{Br})$ と最大エネルギー積 [(BH)max]は磁場中圧縮成形時の磁場配向性に大きく 依存する ${ }^{3,4,6)}$.そこで, 各種配合組成により，異なる平 均崩壊強度を有する粉末を作製し, 磁石特性との関係 を調べた. Fig.6に造粒粉末の平均崩壊強度と磁石特性 の関係を示す.このように, 平均崩壊強度と残留磁束 密度は密接な関係にあり,バインダーの組成, 種類に は依存せず両者はほほ一つの直線関係で表される。す 

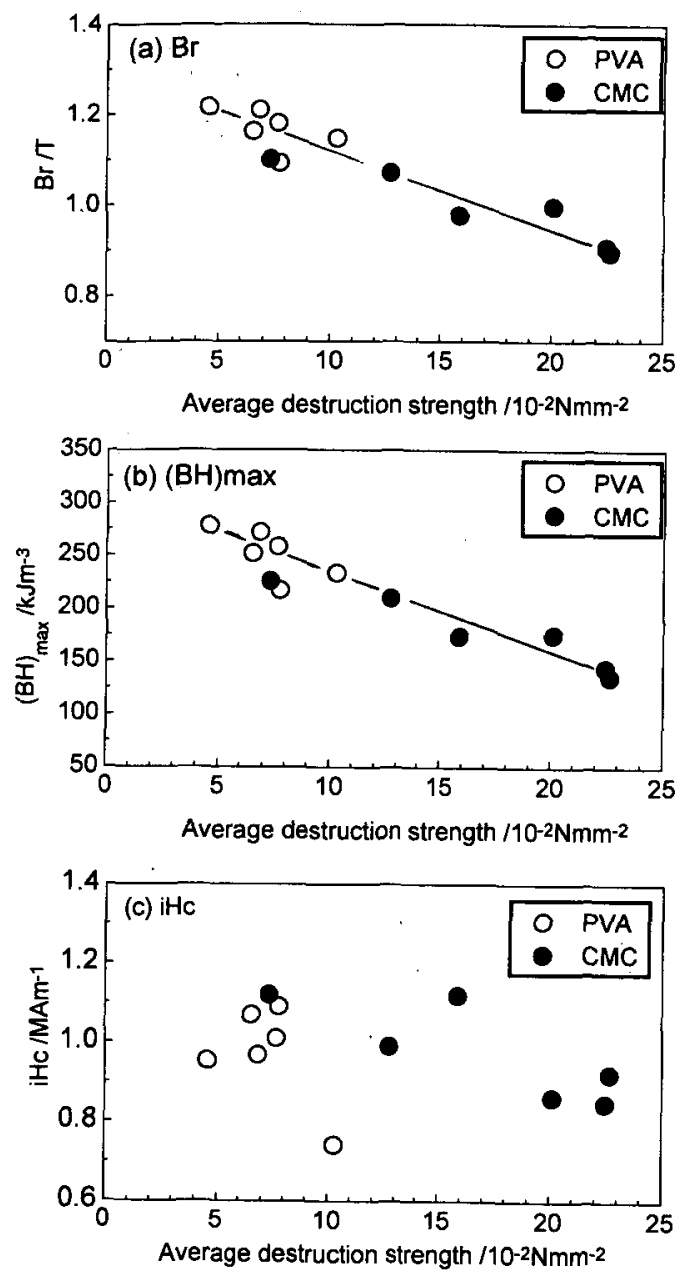

Fig.6 Relations between average destruction strength of granulated powders and (a)remanence, (b)maximum energy product and (c)coercive force of $\mathrm{Nd}-\mathrm{Fe}-\mathrm{B}$ magnets sintered at $1393 \mathrm{~K}$ for $4 \mathrm{H}$ in vacuum.

なわち，造粒粉末を用いて磁場中で成形する場合，成 形体の磁場配向性は，造粒粉末の平均崩壊強度によっ て一義的に決まることを示唆している。

一方, 固有保磁力 $(\mathrm{iHc})$ と造粒粉末の平均崩壊強度 には特に明確な関係は得られず，その結果最大エネル ギー積は残留磁束密度との関係と同様に一つの直線関 係で表わされることが明らかになった。従って得られ る焼結磁石の磁気特性の制御は, 造粒粉末の平均崩壊 強度を制御することにより自由に設計できることにな る、また、これまで造粒粉末を用いて得られる焼結体 の磁気特性は，粉末を成形・焼結しなければ評価でき なかったが, 本評価方法を用いることにより, 得られ る永久磁石の磁石特性を非常に容易にかつ正確にモ二
タすることが可能であることがわかった。これは造粒 粉を用いた焼結磁石の実生産を考えた場合，生産技術 上も非常に有効な手段であると考えられる。

\section{5 平均崩壊強度の温度依存性}

これまでの結果から，造粒粉末を用いた永久磁石の 磁石特性は，造粒粉末の平均崩壊強度によって一義的 に決まり，充分な流動性を確保するためにはある一定 以上の平均崩壊强度が必要であるが, 磁気特性の観点 からは平均崩壊強度はできるだけ低く設定することが 好ましい，ところで，平均崩壊強度に直接関わるバイ ンダーの破断強度は, 温度により大きく変化すること が知られている、従って, 成形時の温度を制御するこ とにより, 平均崩壊強度を制御できるとすれば磁場配 向性の制御が可能となる。このような観点から，平均 崩壊強度および平均崩壊強度を与える粉末密度の温度 依存性を検討した. その結果を Fig.7に示す.このよう に, 圧縮時の粉末温度を変化させても平均崩壊強度を 与える粉末密度はほとんど変化しないが, 平均崩壊強 度は粉末温度の上昇とともに低下寸る。これは，造粒 粉末を構成するバインダー成分が温度上昇とともに軟 化し，破断強度が低下して合金粒子間の結合力が低下 して造粒粉末の保形性が低下したためと考えられる。 これらの事実は，造粒粉末を金型に充填した後，何ら かの手段により加温することにより，磁場中成形時の 磁場配向性が向上し, 得られる磁石特性が向上するこ とが容易に推測できる。

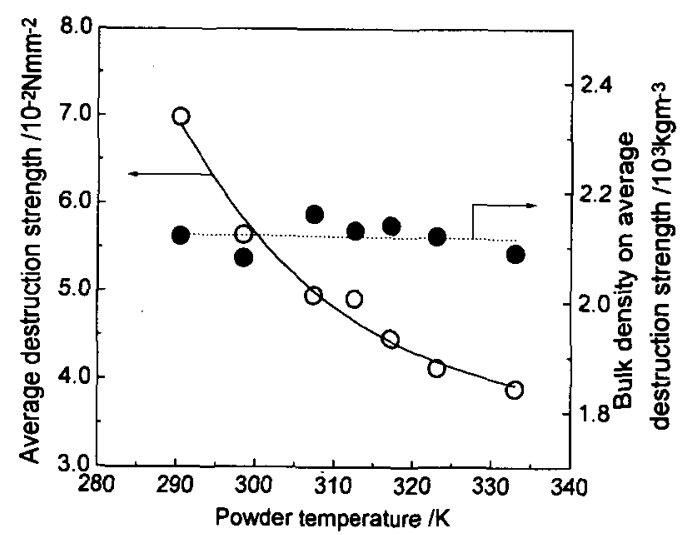

Fig.7 Relations between temperature of granulated powder during compressing and average destruction strength or bulk density on average destruction strength.

\section{4 結 言}

$\mathrm{Nd}-\mathrm{Fe}-\mathrm{B}$ 系造粒粉末の新たな評価方法として，粉末 の圧縮挙動を解析した. 造粒粉末の場合, 圧縮応力ー 
嵩密度プロットにおいて，両者はある屈曲点を有する 二つの直線で表されることがわかった。この届曲点を 与える圧樎応力を平均崩壊強度と定義した。この平均 崩壤強度と, 造粒粉末の粉末特性, 磁気特性の関係を 調べた結果，以下のような知見が得られた。

1)平均崩壊強度はバインダー単体の破断強度と密接な 関係にあり,バインダーの組成を変えて破断强度を制 御することにより造粒粉末の平均崩壊強度を制御する ことが可能である.

2) 平均崩壊強度が約 $0.1 \mathrm{~N} / \mathrm{mm}^{2}$ 以下では崩壊強度の增 加ととも粉末の流動性は向上するが, この值以上では 流動性はほほ一定となる。

3) 得られる焼結磁石の磁気特性 (残留磁束密度, 最大 エネルギー皘) は，平均崩壊強度と密接な関係にあり， バインダーの種類, 組成には関係なく一つの直線関係 で表される、このことは，造粒粉末の磁場配向性は平 均崩壊強度によって一義的に決まることを示唆する。

4) 圧縮時の粉末温度の上昇とともに, 平均崩壊強度は 低下する. 従って，粉末を金型に充填した後加温する ことにより磁石特性を向上させることが可能と考えら

れる.

文献

1) M.Sagawa, S.Fujimura, N.Togawa, H.Yamamoto and Y.Matsuura : J. Appl. Phys., 55 (1984) 2084.

2) K.Master, Spray Drying Handbook, 5th ed. (Long man Scientific \& Technical, England, 1991).

3) 山下治, 岸本芳久: 粉体扰よび粉末治金, 43 (1996) 249.

4) 山下 治, 岸本芳久: 粉体拉よび粉末治金, 43 (1996) 675.

5) 岸本芳久,植田雅巳，山下治: 粉体および粉末治金, 43 (1996) 1449.

6) 岸本芳久,山下治: 粉体执よび粉末治金, 44 (1996) 775 .

7) S.J.Lukasiewcz and J.S.Reed : Ceramic Bulletin, 57 (1978) 798.

8) 辻本広行, 井上義之, 横山豊和, 関口勲: 粉体工学 会1994年度春期研究発表会講演論文集, (1994) 192.

9) U.S.P.5527504 (1996) . 